\title{
Characterization of perch rhabdovirus (PRV) in farmed grayling Thymallus thymallus
}

\author{
Tuija Gadd ${ }^{1, *}$, Satu Viljamaa-Dirks ${ }^{2}$, Riikka Holopainen ${ }^{1}$, Perttu Koski ${ }^{3}$, \\ Miia Jakava-Viljanen ${ }^{1,4}$
}

${ }^{1}$ Finnish Food Safety Authority Evira, Mustialankatu 3, 00790 Helsinki, Finland
${ }^{2}$ Finnish Food Safety Authority Evira, Neulaniementie, 70210 Kuopio, Finland
${ }^{3}$ Finnish Food Safety Authority Evira, Elektroniikkatie 3, 90590 Oulu, Finland
${ }^{4}$ Ministry of Agriculture and Forestry, PO Box 30, 00023 Government, Finland

\begin{abstract}
Two Finnish fish farms experienced elevated mortality rates in farmed grayling Thymallus thymallus fry during the summer months, most typically in July. The mortalities occurred during several years and were connected with a few neurological disorders and peritonitis. Virological investigation detected an infection with an unknown rhabdovirus. Based on the entire glycoprotein $(\mathrm{G})$ and partial RNA polymerase (L) gene sequences, the virus was classified as a perch rhabdovirus (PRV). Pairwise comparisons of the $\mathrm{G}$ and $\mathrm{L}$ gene regions of grayling isolates revealed that all isolates were very closely related, with 99 to $100 \%$ nucleotide identity, which suggests the same origin of infection. Phylogenetic analysis demonstrated that they were closely related to the strain isolated from perch Perca fluviatilis and sea trout Salmo trutta trutta caught from the Baltic Sea. The entire G gene sequences revealed that all Finnish grayling isolates, and both the perch and sea trout isolates, were most closely related to a PRV isolated in France in 2004. According to the partial L gene sequences, all of the Finnish grayling isolates were most closely related to the Danish isolate DK5533 from pike. The genetic analysis of entire G gene and partial L gene sequences showed that the Finnish brown trout isolate ka907_87 shared only approximately 67 and $78 \%$ identity, respectively, with our grayling isolates. The grayling isolates were also analysed by an immunofluorescence antibody test. This is the first report of a PRV causing disease in grayling in Finland.
\end{abstract}

KEY WORDS: Grayling $\cdot$ Perch rhabdovirus $\cdot$ Phylogenetic $\cdot$ Summer mortality $\cdot$ Freshwater

\section{INTRODUCTION}

Of all piscine viruses, rhabdoviruses have the most serious socio-economic impact. More than 14 fish rhabdovirus species from both freshwater and marine fishes have been described (Mork et al. 2004, Hoffmann et al. 2005, Kuzmin et al. 2009, Talbi et al. 2011). The rhabdoviruses causing major epizootics are the novirhabdoviruses viral haemorrhagic septicaemia virus (VHSV) and infectious haematopoietic necrosis virus (IHNV) and the vesiculovirus causing spring viraemia of carp (SVCV). All of these viruses are notifiable to the World Organisation for Animal Health (OIE).
Rhabdoviruses are negative-stranded RNA viruses of the order Mononegavirales and have been isolated from vertebrates, insects and plants (Wagner 1987). The rhabdovirus genome, with a length of approximately 11 to $16 \mathrm{~kb}$, consists of 5 genes in the order $3^{\prime}-$ N-P-M-G-L-5', encoding 5 structural proteins: nucleocapsid $(\mathrm{N})$, phospho- $(\mathrm{P})$, matrix $(\mathrm{M})$, glyco- $(\mathrm{G})$ and RNA polymerase (L) protein (Dietzgen et al. 2011). Within the family Rhabdoviridae, 9 genera are now recognised, of which 3, Novirhabdovirus, Perhabdovirus and Vesiculovirus, infect fish worldwide (ICTV 2013a). All novirhabdoviruses have a sixth nonvirion gene between the $\mathrm{G}$ and $\mathrm{L}$ genes (Kurath et al. 1997, Schütze et al. 1999, Johnson et al. 2000). The 
genera Perhabdovirus and Vesiculovirus comprise an ecologically diverse but genetically similar group of viruses. Perhabdovirus, the new genus of fish rhabdoviruses, includes 3 species: Perch rhabdovirus (PRV), Anguillid rhabdovirus (AngRV) and Sea trout rhabdovirus (STRV). Perhabdoviruses share morphological characteristics, genome organisation and sequence similarities with vesiculoviruses and with viruses in the newly proposed genus Sprivivirus (proposal under revision; ICTV 2013a). SVCV (Ahne et al. 2002) is officially classified as a member of the genus Vesiculovirus, and pike fry rhabdovirus (PFRV) is classified as a tentative member of the genus Vesiculovirus according to the International Committee on Taxonomy of Viruses (ICTV) (Carstens 2010); however, the newly proposed genus Sprivivirus (ICTV 2013b) includes both SVCV and PFRV. For other important fish pathogens such as Siniperca chuatsi rhabdovirus (SCRV), the classification is still under discussion, although their full-length genome sequences are clearly more closely related to those of perhabdoviruses than of members of any other viral genus (ICTV 2013a).

Until 1981, PFRV and SVCV were the only known vesiculo-type viruses responsible for disease epizootics in cultured fish. A rhabdovirus pathogenic for perch Perca fluviatilis was reported in France in 1980 from individuals exhibiting a loss of equilibrium and swimming disturbances (Dorson et al. 1984) and later also from Denmark, Ireland, Germany and Norway (Jørgensen et al. 1993, Dannevig et al. 2001). A PRVlike virus has been associated with diseased grayling Thymallus thymallus in France (Betts et al. 2003). In northern Finland, the brown trout rhabdovirus virus ka903_87 was isolated from farmed brown trout Salmo trutta m. lacustris in 1987 (Koski et al. 1992, Jørgensen et al. 1993).

Here, we describe the isolation and characterization of a PRV that was connected with the summer mortalities of grayling fry in 2 freshwater fish farms.

\section{MATERIALS AND METHODS}

\section{Fish sampling}

Fish samples were received from 2 fish farms, A and B, both situated in a different water catchment area in Finland, but sharing an epidemiological link through transfers of disinfected eggs. In all cases, fish samples were sent to the laboratory alive in oxygenated water and processed on the same day. Virological and bacteriological samples were collected during the pathological examination. Details of grayling sampled for virus isolation are given in Table 1.

\section{Grayling fry mortality}

\section{Farm A (2002)}

A group of grayling fry showed elevated mortality after transfer to larger basins on 2 July. The mortality rate was about $1 \% \mathrm{~d}^{-1}$. A sample of 20 fish was sent to the laboratory on 10 July. Antibiotic treatment was started with oxytetracycline, but it had no effect. The mortality rate was $13.5 \%$ between 10 and 16 July, and a new sample of 20 fish was sent to the laboratory on 16 July. The water temperature at that time was $15.9^{\circ} \mathrm{C}$. The total mortality of this fish group remains uncertain, since the affected fish groups were destroyed after the detection of a viral infection.

\section{Farm B (2003)}

Eyed grayling eggs, disinfected with iodophores, were transferred from the first farm to another fish farm in the lake area. This farm reported elevated mortality in the grayling fry during the period from 10 to 16 July. The average water temperature during this period was $20^{\circ} \mathrm{C}$. The fish were treated with oxytetracycline, but without effect, and a sample of 14 fish was sent to the laboratory on 16 July. The mortality rate of this fish group remains uncertain, since the fish were destroyed.

Table 1. Farms, dates, sample numbers and isolate codes for grayling Thymallus thymallus sampled for virus isolation

\begin{tabular}{|cccccc|}
\hline Farm Sampling & $\begin{array}{c}\text { Sample } \\
\text { date } \\
(\mathrm{dd} / \mathrm{mm} / \mathrm{yy})\end{array}$ & $\begin{array}{c}\text { No. of } \\
\text { samples }\end{array}$ & $\begin{array}{c}\text { No. of } \\
\text { positive } \\
\text { samples }\end{array}$ & $\begin{array}{c}\text { Isolate code } \\
\text { of positive } \\
\text { samples }\end{array}$ \\
\hline A & $10 / 07 / 2002$ & ka706-707_02 & 2 & 2 & ka706-707_02 \\
A & $16 / 07 / 2002$ & ka712_02 & 1 & 1 & ka712_02 \\
B & $16 / 07 / 2003$ & ka672_03 & 1 & 1 & ka672_03 \\
A & $01 / 07 / 2009$ & ka495-496_09 & 2 & 1 & ka495_09 \\
A & $13 / 07 / 2009$ & ka512-524_09 & 13 & 7 & ka512_09, ka519-524_09 \\
A & $10 / 09 / 2009$ & ka 626-655_09 & 30 & 1 & ka 636_09 \\
A & $27 / 07 / 2010$ & ka501_10 & 1 & 1 & ka501_10 \\
\hline
\end{tabular}




\section{Farm A (2009)}

During the start of the feeding period in June, exceptionally high mortality was noted in groups of grayling fry. Mortality normally remains around $10 \%$, but reached up to $80 \%$ at this time. The first sample was sent to the laboratory on the first day of July, when the fish were transferred to 5 larger basins. The water temperature at this time was $15.2^{\circ} \mathrm{C}$.

Follow-up samples were sent to the laboratory on 13 July, when the mortality in on-growing basins had reached about $5 \%$. At the same time, the fry from the 3 most affected basins were destroyed, because of the suspicion of a viral infection. In the 2 remaining groups, the mortality rates remained high (5 and 13\%), and new samples were sent to the laboratory in September. At the same time, antibiotic treatment was started with oxytetracycline. This treatment had no effect on mortality, and the fish were destroyed on 15 October, when the total mortality reached $20 \%$.

\section{Farm A (2010)}

The mortality rate in a group of grayling fry increased from the daily $0.1-0.4 \%$ to $2 \%$ at the end of July. Some of the fish exhibited spiral swimming.

\section{Pathology and bacteriology}

The fish were investigated according to routine laboratory practices (Midtlyng et al. 2000). Briefly, the fish were examined for parasites by direct microscopy of the gills and skin scrapings. Bacteriological investigations were conducted by direct streaking from the kidney, spleen, brain or, in the case of small fish, body cavity on blood agar and Anacker and Ordal medium for flavobacteria. A number of fish fry were fixed as whole fish in $10 \%$ neutral buffered formalin, embedded in paraffin, sectioned at $4 \mu \mathrm{m}$ and stained with haematoxylin and eosin (H\&E) according to the standard laboratory practice. For bigger fry, only the anterior part of the body was treated in this way.

\section{Virus isolation}

Pooled brain, anterior kidney and spleen tissues from a maximum of 10 fish were processed according to standard virological procedures as described by Raja-Halli et al. (2006) and inoculated onto subconfluent monolayer cell cultures of bluegill fry (BF-2, Wolf et al. 1966) and epithelioma papulosum cyprini (EPC, Fijan et al. 1983) cell lines.

Originally the samples were incubated at $16^{\circ} \mathrm{C}$ in $\mathrm{CO}_{2}$. Starting in 2009, the samples were buffered with sodium carbonate $7.5 \%$ (Gibco 25080) and incubated without $\mathrm{CO}_{2}$. The samples were inspected regularly under a microscope for the occurrence of cytopathic effect (CPE). After $7 \mathrm{~d}$ of incubation, supernatant from samples without CPE was diluted 1:100 and 1:1000, sub-cultured onto fresh cells and incubated for a further $7 \mathrm{~d}$. In cases where total CPE was evident, the cell culture medium was collected and stored at $-70^{\circ} \mathrm{C}$ for future studies.

\section{ELISA for IHNV, infectious pancreatic necrosis virus (IPNV), SVCV and VHSV}

Aliquots of $50 \mu \mathrm{l}$ of culture medium from cell cultures showing evidence of CPE were analysed with commercial ELISA kits according to the manufacturer's instructions to test for the presence of IPNV, SVCV, VHSV (Test-Line), and since 2008, also for the presence of IHNV (Bio-X Diagnostics S.P.R.L).

\section{Indirect fluorescent antibody test (IFAT) for detection of perhabodoviruses}

IFAT was used for virus identification. Cover glass (diameter $13 \mathrm{~mm}$, Menzel-Glaser) cultures of EPC cells grown in 24-well plates were inoculated with viruses at dilutions of $10^{-1}$ and $10^{-2}$. Brown trout rhabdovirus ka903_87 was used as a positive control and VHSV and uninfected cells as negative controls. The infected cultures were fixed with acetone on Days 1 and 2 post-infection, and the IFAT technique was performed as described previously (Lorenzen et al. 1988). Briefly, the rabbit anti-PRV F28 (provided by the European Union Reference Laboratory for Fish Diseases, EURL, National Veterinary Institute, Technical University, Aarhus, Denmark) and rabbit anti-brown trout rhabdovirus ka903_87 (Monta 30052) (EURL) was diluted in phosphate-buffered saline and applied as the first antibody on the monolayer. After 30 min incubation at $37^{\circ} \mathrm{C}$, diluted fluorescein isothiocyanate-labelled swine anti-rabbit immunoglobulin was added as the second antibody (DAKO $\mathrm{A} / \mathrm{S}$ ), and incubated for $30 \mathrm{~min}$ at $37^{\circ} \mathrm{C}$. The mono- 
layer was washed and examined under an epifluorescence microscope.

\section{PCR and sequencing}

RNA was isolated from infected cell cultures using the QIAamp Viral RNA Mini Kit (Qiagen) according to the manufacturer's instructions. cDNA was generated either separately or in a 1-step PCR reaction. The reaction mix for the separate cDNA synthesis contained $2.5 \mu \mathrm{M}$ random primers (Random Hexamers, Applied Biosystems), $2 \mu \mathrm{l} 10 \times$ buffer II (Applied Biosystems), $2 \mathrm{mM}$ dNTPs (Applied Biosystems), $2.5 \mathrm{mM} \mathrm{MgCl}_{2}, 20$ units of RNase Inhibitor (Applied Biosystems), 150 units of MuLV Reverse Transcriptase (Applied Biosystems) and $5 \mu \mathrm{l}$ of RNA. The reactions were incubated at $37^{\circ} \mathrm{C}$ for $90 \mathrm{~min}$ and stored at $-70^{\circ} \mathrm{C}$ until further use.

Several primers were used to amplify partial fragments of viral glycoprotein (G) and RNA polymerase (L) genes. At first, primers GF (5'TGT CCD ATR CAH GGA RAT YT3') and GR (5'THT BAT CTG YKA KCC AAA3') were designed based on published glycoprotein gene sequences of brown trout rhabdovirus ka930_87 (GenBank ID: AF320088), SVCV (GenBank ID: EU177782) and PFRV (GenBank ID: FJ872827). The expected amplicon size was 528 bp in length. However, these primers failed to amplify the partial G gene from the perch and grayling isolates studied. Therefore, new primer pairs oPVP116 (5'ACW TGT GAY TWC MGW TGG TAT GG3') and oPVP118 (5'CTG TTA GCT GTT TTT TTC ATA3'), and oPVP126 (5'GAT ATG AAA AAA ACT GCA ACA G3') and Rha-G-seqR2 (5'GAG GAG TCC TCT ATG TTG GTC3') were used in order to obtain the complete viral G gene sequence in 2 overlapping fragments. Primers oPVP116, oPVP118 and oPVP126 were published by Talbi et al. (2011), and primer Rha-G-seqR2 was designed based on sequences obtained in this study. The expected amplicon size for primers oPVP116\&oPVP118 was approximately 1400 bp (Talbi et al. 2011) and for primers oPVP126\&Rha-G-seqR2, it was $676 \mathrm{bp}$. The primers LF (5'CTC TGA TGT CAT GGG AAY TG3') and LR (5'CAT CCC AAC AGA CAA GCY TGT C3') were used to amplify a $399 \mathrm{bp}$ fragment of the $\mathrm{L}$ gene. The primer design was based on viral $\mathrm{L}$ gene sequences previously published by Betts et al. (2003). For primer pairs GF + GR and $\mathrm{LF}+\mathrm{LR}$, the $\mathrm{PCR}$ reaction mix contained $5 \mu \mathrm{l}$ of $10 \times$ PCR buffer (Finnzymes, Thermo Fisher Scientific), 2 U Dynazyme II DNA polymerase (Finnzymes), $0.5 \mu \mathrm{M}$ of forward and reverse primer,
$200 \mu \mathrm{M}$ dNTP (Finnzymes), $500 \mu \mathrm{M} \mathrm{MgCl}, 5 \mu \mathrm{l}$ of cDNA template and water up to the final volume of $50 \mu \mathrm{l}$. The PCR conditions were as follows: initial pre-heating step of $10 \mathrm{~min}$ at $95^{\circ} \mathrm{C}, 25$ cycles of $94^{\circ} \mathrm{C}$ for $1 \mathrm{~min}, 50^{\circ} \mathrm{C}$ for $2 \mathrm{~min}$ and $72^{\circ} \mathrm{C}$ for $2 \mathrm{~min}$, followed by a final extension step of $15 \mathrm{~min}$ at $72^{\circ} \mathrm{C}$. With primers oPVP116+oPVP118 and oPVP126+Rha-GseqR2, the Qiagen Onestep RT-PCR Kit was used according to the manufacturer's instructions, with $5 \mu$ of RNA as a reaction template. The 1-step PCR protocol was as follows: cDNA synthesis at $50^{\circ} \mathrm{C}$ for 30 min, deactivation of reverse transcriptase and activation of DNA polymerase at $95^{\circ} \mathrm{C}$ for $15 \mathrm{~min}$, 35 cycles of $94^{\circ} \mathrm{C}$ for $30 \mathrm{~s}, 42^{\circ} \mathrm{C}$ for $30 \mathrm{~s}$ and $72^{\circ} \mathrm{C}$ for $1 \mathrm{~min}$, followed by a final extension step of $7 \mathrm{~min}$ at $72^{\circ} \mathrm{C}$. PCR products were visualized by gel electrophoresis and sequenced with both the forward and reverse PCR primers using the Big Dye Terminator v1.1 Cycle Sequencing Kit (Applied Biosystems) and an ABI PRISM 3100-Avant Genetic Analyzer (Applied Biosystems). For sequencing the complete $\mathrm{G}$ gene, primers oPVP116, oPVP118, oPVP126 and Rha-G-seqR2 were used. The raw sequence data were analysed using Sequencing Analysis Software 5.1 (Applied Biosystems). The assembly of the G gene sequence data was accomplished using SeqScape Software 3 (Applied Biosystems).

\section{Analysis of sequence data}

To determine the similarity of grayling isolates to other published fish rhabdovirus isolates, a nucleotide similarity search (BLAST) was performed (www. ncbi.nlm.nih.gov) and a number of representative fish perhabdovirus, vesiculovirus and vesiculo-type rhabdovirus isolates were selected to further analyse the genetic relationships (summarised in Table 2). The multiple sequence alignments were performed with the MegAlign program using the Clustal Method (DNASTAR) and ClustalW2 software (Larkin et al. 2007). Phylogenetic and molecular evolutionary analyses were conducted using MEGA version 5 (Tamura et al. 2011). Phylogenetic trees were constructed from the partial L gene and the entire G gene with the maximum likelihood method determined by 1000 bootstrap resamplings within the MEGA 5 program. The pairwise sequence divergences were calculated using the MegAlign program of LASERGENE, with default settings. The GenBank/EMBL accession numbers of the sequences obtained in this study are KC408697-KC408701 (L gene) and KF146308-KF146315 (G gene). 
Table 2. Representative rhabdovirus isolates used for phylogenetic analysis (including the accession number, if available) representing the sequenced isolates

\begin{tabular}{|c|c|c|c|c|c|c|}
\hline Virus name & Isolate code & Origin & $\begin{array}{c}\text { Host } \\
\text { species }\end{array}$ & $\begin{array}{l}\text { Accession } \\
\text { no. L gene }\end{array}$ & $\begin{array}{l}\text { Accession } \\
\text { no. G gene }\end{array}$ & Source \\
\hline Perch rhabdovirus & ka706_02_grayling & Finland & Grayling & KC408701 & KF146312 & This study \\
\hline Perch rhabdovirus & ka672_03_grayling & Finland & Grayling & KC408700 & KF146311 & This study \\
\hline Perch rhabdovirus & ka512_09_grayling & Finland & Grayling & - & KF146308 & This study \\
\hline Perch rhabdovirus & ka521_09_grayling & Finland & Grayling & KC408698, & KF146309 & This study \\
\hline Perch rhabdovirus & ka636_09_grayling & Finland & Grayling & KC408699 & KF146310 & This study \\
\hline Perch rhabdovirus & ka501_10_grayling & Finland & Grayling & - & KF146315 & This study \\
\hline Perch rhabdovirus & ka177_03_perch & Baltic Sea & Perch & KC408697 & KF146314 & This study \\
\hline Perch rhabdovirus & ka848_09_sea_trout & Baltic Sea & Sea trout & - & KF146313 & This study \\
\hline Perch rhabdovirus & 4890 & France & Pikeperch & - & JF502607 & Talbi et al. (2011) \\
\hline Perch rhabdovirus & $27 \mathrm{~V} 10$ & Italy & Perch & - & JF502605 & Talbi et al. (2011) \\
\hline Perch rhabdovirus & P8350 & France & Perch & - & JF502609 & Talbi et al. (2011) \\
\hline Perch rhabdovirus & N4925 & France & Perch & - & JF502604 & Talbi et al. (2011) \\
\hline Perch rhabdovirus & DK5533 & Denmark & Pike & - & JF502603 & $\begin{array}{l}\text { Jørgensen et al. (1993), } \\
\text { Betts et al. (2003) }\end{array}$ \\
\hline Perch rhabdovirus & grayling_47_90 & France & Grayling & - & - & Betts et al. (2003) \\
\hline Perch rhabdovirus & PRV & France & Perch & JX679246 & JX679246 & $\begin{array}{l}\text { Dorson et al. (1984), } \\
\text { Stone et al. (2013) }\end{array}$ \\
\hline $\begin{array}{l}\text { Sea trout } \\
\text { rhabdovirus }\end{array}$ & $\begin{array}{l}\text { ka 907_87_ } \\
\text { brown_trout }\end{array}$ & Finland & Brown trout & AF434991 & AF434991 & $\begin{array}{l}\text { Koski et al. (1992), } \\
\text { Johansson et al. (2001) }\end{array}$ \\
\hline Sea trout rhabdovirus & SSTV 28/97 & Sweden & Sea trout & AF434992 & AF434992 & Johansson et al. (2001) \\
\hline Sea trout rhabdovirus & O403467 & France & Black bass & - & JF502596 & Talbi et al. (2011) \\
\hline Sea trout rhabdovirus & R6147 & France & Perch & - & JF502608 & Talbi et al. (2011) \\
\hline Anguillid rhabdovirus & EVEX & Netherlands & Eel & FN557213 & FN557213 & Galinier et al. (2012) \\
\hline $\begin{array}{l}\text { Siniperca chuatsi } \\
\text { rhabdovirus }\end{array}$ & SCRV & China & Mandarin fish & DQ399789 & DQ399789 & Tao et al. (2008) \\
\hline $\begin{array}{l}\text { Spring viraemia } \\
\text { of carp virus }\end{array}$ & SVCV_A1 & China & Common carp & DQ097384 & DQ097384 & Teng et al. (2007) \\
\hline $\begin{array}{l}\text { Spring viraemia } \\
\text { of carp virus }\end{array}$ & SVCV_Fijan & Europe & Common carp & AJ318079 & AJ318079 & Hoffmann et al. (2005) \\
\hline Pike fry rhabdovirus & PFRV & Netherlands & Pike & FJ872827 & FJ872827 & $\begin{array}{l}\text { Kinkelin et al. (1973), } \\
\text { Chen et al. (2009) }\end{array}$ \\
\hline
\end{tabular}

\section{RESULTS}

\section{Clinical signs, bacteriology and pathology}

In July 2002, the fish from Farm A showed spiral swimming and breathing difficulties, especially the better-developed individuals. Several fish had a distended abdomen. One fish had a few haemorrhagic spots in the pyloric area of the abdominal fat, combined with slimy intestinal contents, anaemic inner organs and a patchy liver. Histology revealed peritonitis as an infection of abdominal fat tissue around the pyloric caeca (Fig. 1). No parasites or bacterial infections were detected. In the first sample from 2009, several fish exhibited spiral swimming. Some of them had flared operculae and breathing problems. The head was large compared to the body.

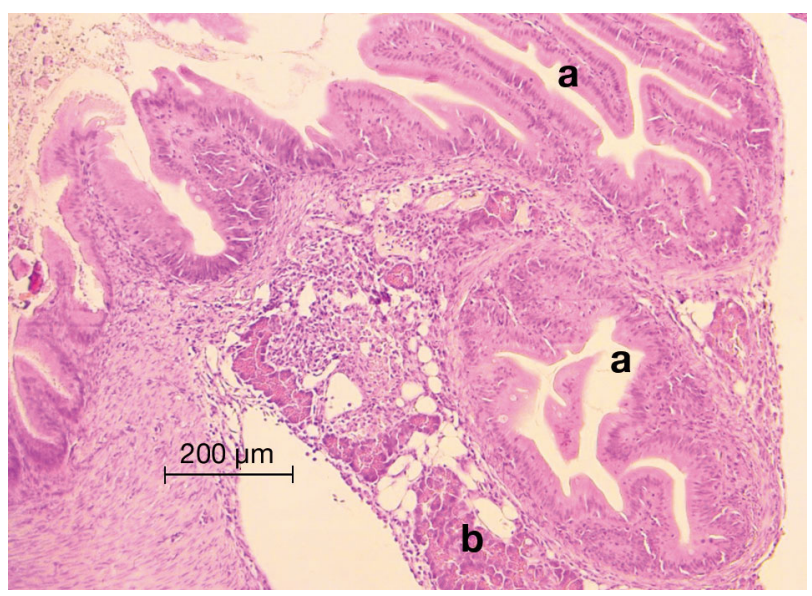

Fig. 1. Thymallus thymallus. Peritonitis in grayling fry in 2003 seen in the abdominal fat tissue around the pyloric caeca (a). Exocrine pancreatic cells (b) are still normal 
Some fish had exophthalmia. Microscopic examination was negative for parasites and superficial bacteria, but excessive numbers of bacteria were present in the otherwise empty-looking intestine in some fish. In bacteriological study, unidentifiable flavobacteria (Flavobacterium sp.) were found from the abdominal cavity among a mixed bacterial growth in 3 out of 9 fish, the remaining fish being negative. The histological study revealed extensive peritonitis even involving pancreatic tissue (Fig. 2), as well as necrotic areas in the liver parenchyma. Follow-up samples were investigated virologically from all basins with grayling fry, with and without clinical signs. The virus could be isolated from clinical and sub-clinical groups. The sub-clinical groups remained at the farm until September, when new samples were collected for bacteriological and virological study. A few fish had skin sores, from which F. columnare was isolated; otherwise, the bacteriological study was negative. In the 2010 case, most of the fish had breathing difficulties, and almost all exhibited spiral swimming. The pyloric area was slightly haemorrhagic. Parasites were not detected. The histological study again revealed peritonitis with a heavy involvement of abdominal fat in the pyloric area. Bacteriological investigation was negative. The fish from Farm B were unevenly grown, and a few were emaciated. Some of the fish were bent sideways. A small amount of slimy excreta was observed hanging from the anus. One fish showed some pinpoint haemorrhages in the pyloric area of the abdominal fat. In direct microscopy, extensive numbers of bacteria were detected in the abdominal cavity, but no parasites were seen. The gills were swollen. Bacteriological study was negative for specific pathogens.

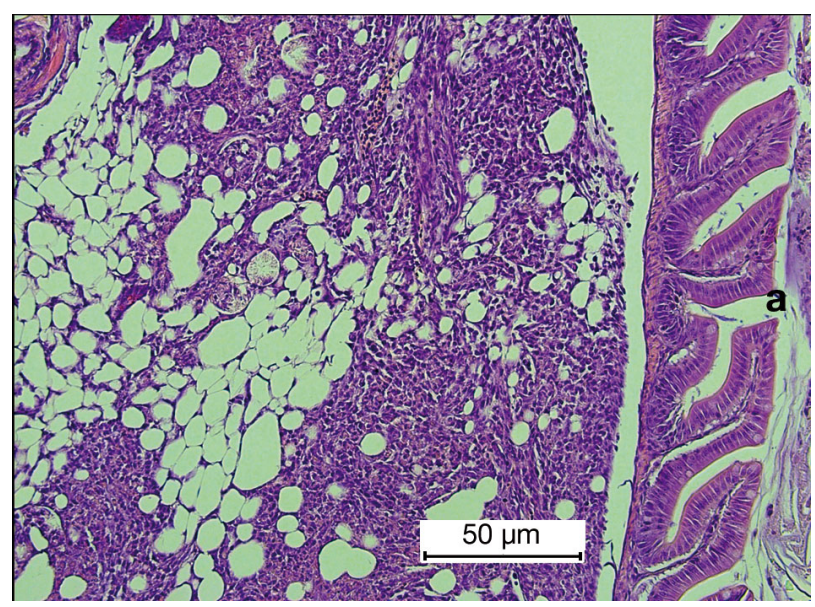

Fig. 2. Thymallus thymallus. Extensive peritonitis in the abdominal fat tissue of grayling fry in 2009, also affecting the pancreatic cells. a: pyloric caecum

\section{Virus isolation and identification}

PRV was isolated from 13 pooled samples from Farm A during 2002, 2009 and 2010 and from 1 pooled sample from Farm B in 2003. Isolates were initially identified as rhabdoviruses by the typical associated CPE on BF-2 and EPC cell lines. Ka706_02 and ka672_03 were confirmed as PRV-like viruses in the EURL for Fish Diseases by a plaque neutralisation test.

\section{ELISA for the detection of IHNV, IPNV, SVCV and VHSV}

ELISA tests were negative for the presence of IHNV, IPNV, SVCV and VHSV in all samples studied.

\section{IFAT}

BF-2 cells infected with viruses from grayling were stained in IF applying rabbit antisera against brown trout rhabdovirus ka903_87 and PRV F28. The intensity of the reaction varied from weak to strong. A serological cross-reaction between brown trout rhabdovirus ka903_87 and PRV was also observed. The most intense staining was observed with both rabbit antisera against some grayling isolates. Ka903_87 isolated from brown trout exhibited a strong signal with homologous antiserum, but was only weakly stained with the antiserum to PRV F28. VHSV was not detected with IFAT (results not shown).

\section{PCR}

Primers GF and GR produced a PCR product of the expected size from brown trout rhabdovirus ka903_87, while no products were obtained from the grayling isolates or PRV ka177_03. The complete G gene sequence of the grayling, perch and sea trout isolates was obtained in 2 overlapping fragments using primer pairs oPVP116+oPVP118 and oPVP$126+$ Rha-G-seqR2, and the length of the open reading frame was $1560 \mathrm{bp}$ for all isolates. Primers LF and LR produced PCR products of the expected size from the grayling isolates and PRV ka177_03. Only a very weak PCR product was obtained from the sea trout isolate ka848_09, while no product was obtained from brown trout rhabdovirus ka903_87. 


\section{Genetic analysis}

The partial L gene sequences (397 nucleotides, nt positions 6280-6676 of the SVCV complete genome sequence U18101) were determined from 4 representative isolates of grayling strains isolated between 2002 and 2009 and the isolate from wild perch from the Baltic Sea (Table 2). Due to the weak PCR product, we were not able to obtain any sequence data from the sea trout isolate ka848_09. Pairwise comparisons of the $\mathrm{L}$ gene sequences and the phylogenetic analysis revealed that all grayling isolates were closely related to each other, with approximately 99.0 to $100 \%$ nucleotide homology. The Finnish perch isolate ka177_03 was closely related to the grayling isolates, with approximately $97.5 \%$ nucleotide homology (data not shown).

Sequences of the entire G gene (1560 nt) for the 6 representative grayling isolates and the isolates from wild perch ka177_03 and sea trout ka848_09 isolated from the Baltic Sea were determined. Pairwise comparisons of the entire G gene sequences and the phylogenetic analysis revealed that all grayling isolates were closely related to each other, with approximately 98.8 to $100 \%$ nucleotide homology. The Finnish perch isolate ka177_03 and sea trout isolate ka848_09 were closely related to the grayling isolates, with 95.4 and $96.1 \%$ nucleotide homology (data not shown).

Maximum likelihood analysis of the partial L gene sequences revealed that all Finnish grayling isolates and both the perch and sea trout isolates were most closely related to the Danish isolate DK5533 from pike, as they shared 92.2 to $93.2 \%$ identity. They shared 90.7 to $91.2 \%$ nucleotide identity with the rhabdovirus PRV_80, isolated from perch in 1980 in France. On the other hand, maximum likelihood analysis of the entire G gene sequences revealed that all Finnish grayling isolates as well as the perch and sea trout isolates were most closely related to PRV isolates from perch (PRV_80, 27V10) and pikeperch (4890), sharing 88.4 to $90.0 \%$ identity, and to the isolate DK5533 from pike, sharing 88.3 to $89.1 \%$ identity. The genetic analysis of the partial L gene sequences showed that the brown trout isolate ka907_87, a rhabdovirus isolated from an area geographically close to the isolation sites of the grayling viruses, shared only 77.6 to $78.6 \%$ identity with the grayling isolates. The genetic analysis of entire G gene sequences revealed that the brown trout isolate ka907_87 shared only 66.9 to $67.2 \%$ identity, respectively, with the Finnish grayling isolates.
The genetic relationships of all Finnish PRV isolates are illustrated in Fig. 3, which was created from the alignment of the partial L gene region (397 nt; Fig. 3a) and the entire G gene (1560 nt; Fig. 3b).

\section{DISCUSSION}

The grayling is a salmonid fish that has no value for food fish production purposes in Finland, but is a popular species for restocking and sport fisheries. The grayling is known as a challenging species for intensive farming, mostly due to its sensitivity to several disease agents. This may also reflect limited knowledge of the environmental and nutritional demands of grayling, especially as fry during the first summer. Grayling fry often show clinical signs and mortality for unrecognisable reasons. Here, we describe summer mortality affecting grayling fry that seems to be caused by a previously unknown rhabdovirus. The recurring nature of the same types of clinical signs connected with mortality, and the consistent isolation of the same type of virus in the affected fry seems to justify the assumption that the virus is the cause of the problems, although experimental infection of grayling has not been performed.

All diseased groups showed some neurological disorders typical for viral infection. The disease was, however, best characterized by severe peritonitis that developed in the abdominal fat tissue and in the later stage also involved the pancreatic tissue. Haemorrhaging was much less often seen, as was necrosis in the other organs. Inflammation of the peritoneum has also been described in spring viraemia of carp along with other clinical signs (Bachmann \& Ahne 1973).

Talbi et al. (2011) divided similar fish vesiculo and vesiculo-type viruses into 2 major clusters (I and II). All rhabdoviruses isolated from perch fell into the same cluster, which was divided into 8 distinct genogroups $(\mathrm{A}-\mathrm{H})$ supported by high bootstrap values (76-100\%) with $\mathrm{G}$ and partial $\mathrm{N}$ gene sequences (Talbi et al. 2011). Genogroup A contained rhabdoviruses isolated from perch in France and Italy between 1980 and 2002 and B included strains that were later isolated from farms in the same region (2004-2009). Genogroup C contained only 1 rhabdovirus, isolated from pike in Denmark (DK5533), and D contained 1 isolate from perch in France. Genogroup E consisted of 2 nearly identical isolates from perch and black bass from France, as well as an isolate from sea trout from Sweden (SSRV) and from brown trout from Finland (ka903_87). The AngRV 
a
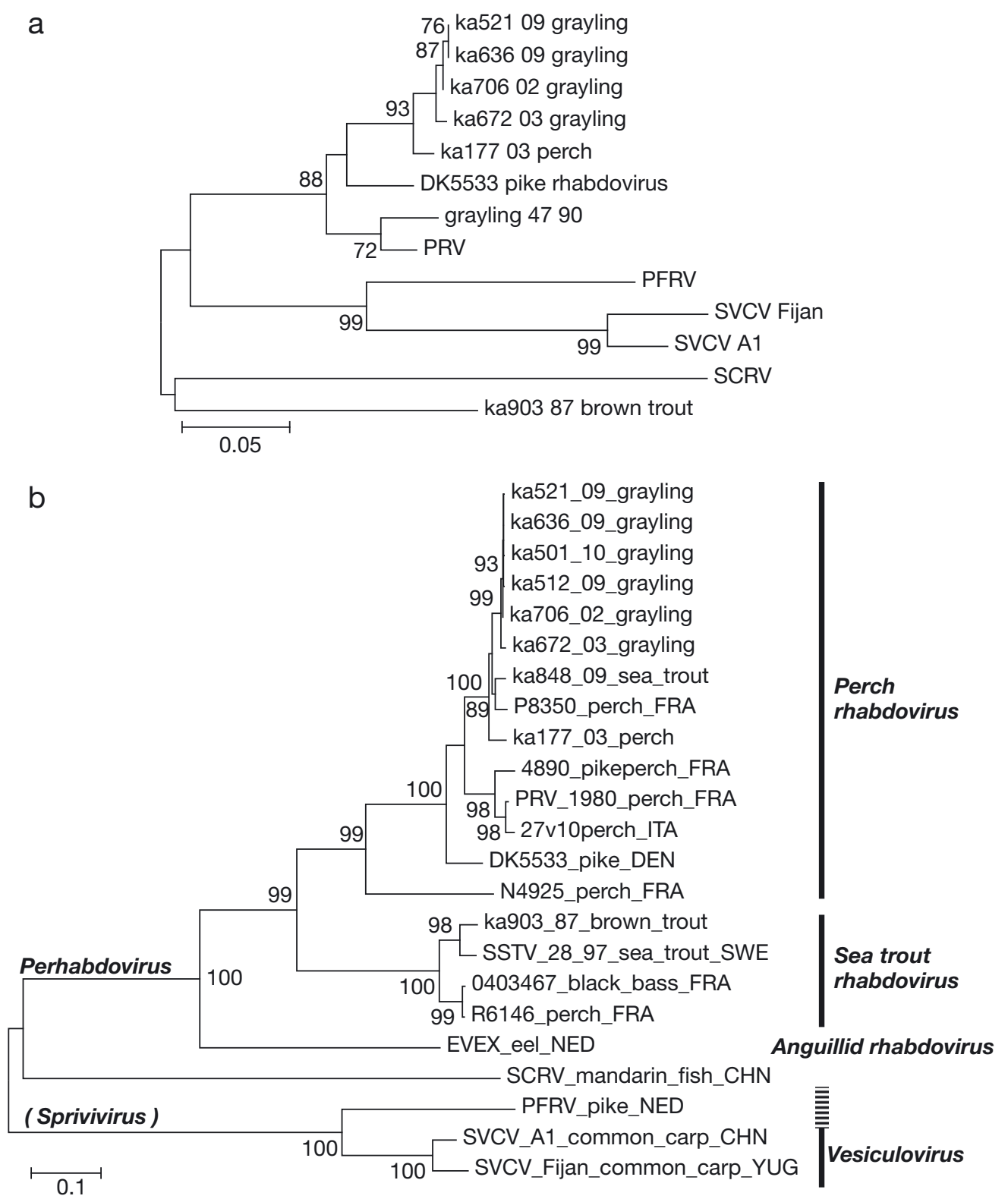

Fig. 3. Maximum likelihood phylogenetic trees obtained using (a) the partial L gene (397 nt) of vesiculo or vesiculo-type rhabdoviruses and (b) the entire G gene (1590 nt; perch rhabdovirus, PRV) of perhabdo-, vesiculo- or vesiculo-type rhabdoviruses. Short horizontal lines in (b) indicate that classification of PFRV as a vesiculovirus is tentative. It has now been proposed that SVCV and PFRV be placed in a new genus, Sprivivirus (ICTV 2013b). Bootstrap values are indicated at the nodes for a total of 1000 replicates, and values $>70$ are shown on the tree. Sequence alignments were performed using ClustalW2. The phylogenetic tree was constructed using the maximum likelihood method within the MEGA 5 program. The origins of the representative virus isolates used for phylogenetic analysis are shown in Table 2. Scale bars indicate nucleotide substitutions per site

(EVEX) and SCRV fell into the Genogroups G and H, respectively (Talbi et al. 2011). According to ICTV (2013a), Genogroup E is STRV and Genogroup G is AngRV in the genus Perhabdovirus, while Genogroup $\mathrm{H}$ is unclassified.

Phylogenetic analysis of both the entire $\mathrm{G}$ and partial L genes placed grayling isolates in the PRV group within the perhabdoviruses in this study. G gene sequences revealed that all Finnish grayling isolates as well as the perch and sea trout isolates were most closely related to PRV isolated from France in 2004. Isolates from perch from France in 1980 and from Italy in 2010, pikeperch from France in 1990 and the Danish isolate DK5533 from pike in 1994 were also closely related to our grayling isolates. The isolate DK5533 was most closely related to Finnish grayling 
isolates in an analysis of the partial L gene sequences. The partial L gene sequences also revealed that all Finnish grayling and perch isolates were closely related to the French PRV_80 isolated in 1980 from perch. The genetic analysis of entire G gene and partial L gene sequences revealed that the brown trout isolate ka907_87 shared only approximately 67 and $78 \%$ identity, respectively, with our grayling isolates. These results are consistent with a previous analysis of a conserved region of the $L$ gene, in which PRV was clearly separated from SVCV, PFRV and ka903_87 (Betts et al. 2003). However, 1 of the newly described French perch isolates from Genogroup E-or according to ICTV (2013b), STRV - was more distantly related to the others, displaying a relatively high divergence from the other perch viruses (Talbi et al. 2011). Our phylogenetic analysis also confirmed a split between a genetic cluster formed by SVCV and PFRV and a cluster (genus Perhabdovirus) containing a number of grayling, perch, black bass and pikeperch isolates, including those described in this study and by others (Dorson et al. 1984, Nougayrede et al. 1992, Jørgensen et al. 1993, Johansson et al. 2001, 2002, Talbi et al. 2011, ICTV 2013a). The origin or reservoir of the Finnish grayling rhabdovirus has not been clarified. Talbi et al. (2011) observed a very close genetic relationship between one French PRV and the Finnish brown trout rhabdovirus ka907_87. According to ICTV (2013a), these strains belong to the species STRV. Additionally, a similar relationship was observed between an isolate from diseased perch from Lake Arungen, which has a connection to seawater in Norway, and the Finnish brown trout rhabdovirus ka907_87 (Dannevig et al. 2001).

Brown trout may carry a PFRV-related virus under farmed conditions without clinical signs (Adair 1986, Rowley et al. 2001). Migrating trout and pike are suspected to carry viruses with a potential for transmission to perch and other freshwater species, and have an important role as carrier hosts when migrating from the marine environment to freshwater (Talbi et al. 2011). Similarly to Talbi et al. (2011), we also confirmed a rather close genetic relationship between our grayling isolates and the pike isolate DK5533 and PRV. However, the Finnish brown trout rhabdovirus ka903_87 isolate was clearly distinguishable from all other Finnish isolates originating from grayling, perch and sea trout. The possible role of the brown trout rhabdovirus as a threat to grayling aquaculture remains unclear. There has been no migration of sea trout or other migratory fish between the Baltic Sea and the locations of the fish farms in this study due to migration barriers in the river systems. Thus, mechanisms other than natural fish migration from the sea are probably a more likely source of the virus in this study. The disease in Farm B was clearly connected with the transfer of disinfected grayling eggs from Farm A, but whether it was true vertical transmission or an unsuccessful process of disinfection remains unclear.

The brown trout rhabdovirus ka903_87 isolated from brown trout in Finland in 1987 was shown to cross-react serologically with a rhabdovirus isolated from pike in the IFAT (Koski et al. 1992, Jørgensen et al. 1993, Björklund et al. 1994), and is also genetically related to the Swedish sea trout virus (SSTV) isolated in 1996 from sea trout Salmo trutta m. trutta from the archipelago of Stockholm, Baltic Sea (Johansson et al. 2001). However, the primers GF and GR designed in this study based on the published glycoprotein gene sequences of brown trout rhabdovirus ka930_87, SVCV and PFRV did not amplify any of the grayling virus isolates, although PAb ka903_87 crossreacted with grayling isolates in IFAT in our laboratory. The first isolation of a rhabdovirus from perch in Norway cross-reacted serologically with brown trout rhabdovirus ka903_87 (Dannevig et al. 2001), but unfortunately no sequence data are available. It appears to be difficult to distinguish between perhabdoviruses and vesiculo-type rhabdoviruses using the serological assays recommended by the OIE (Rowley et al. 2001, Way et al. 2003, Dixon \& Longshaw 2005). Using a panel of antisera against brown trout rhabdovirus ka903_87, PRV F28 and VHSV in IFAT, the grayling isolates were identified as a perhabdovirus. It was impossible to distinguish between brown trout rhabdovirus ka903_87 and grayling isolates by IFAT in our laboratory.

Challenge experiments have shown that the Finnish grayling isolates are not pathogenic to rainbow trout fingerlings by immersion or intraperitoneal injection under experimental conditions at $9-12^{\circ} \mathrm{C}$ (K. Einer-Jensen unpubl. results). Similarly, Jørgensen et al. (1993) and Dannevig et al. (2001) found that the PFRV and the PRV were not pathogenic to rainbow trout. There is a need to further investigate the pathogenicity of Finnish PRV isolated from grayling fry to other important species in Finnish aquaculture.

There is a great need to develop better diagnostic tools, especially PCR-based methods, for the detection of perhabdoviruses. This is particularly important in farms and areas where other fish rhabdoviruses are also present. Further sequencing work is required to investigate the relationship between 
PRV and other perhabdoviruses. Improved knowledge will help in understanding the genetic diversity, transmission routes and hosts of perhabdoviruses.

Acknowledgements. We thank the staff of the Finnish Game and Fisheries Research Institute, especially R. Kannel, for help in the study. The staff at the Research and Laboratory Department of Evira, especially K. Leino, H. Kauno, T. Seppänen, C. Ek-Kommonen, S. Sainmaa, U. Rikula, M. Hautala, P. Raikunen and A. Palva, are acknowledged for their contribution.

\section{LITERATURE CITED}

Adair BM (1986) Isolation of pike fry rhabdovirus from brown trout (Salmo trutta). Bull Eur Assoc Fish Pathol 6: 85-86

Ahne W, Bjorklund HV, Essbauer S, Fijan N, Kurath G, Winton JR (2002) Spring viremia of carp (SVC). Dis Aquat Org 52:261-272

Bachmann PA, Ahne W (1973) Isolation and characterization of agent causing swim bladder inflammation in carp. Nature 244:235-237

Betts AM, Stone DM, Way K, Torhy C, Chilmonczyk S, Benmansour A, de Kinkelin P (2003) Emerging vesiculo-type virus infections of freshwater fishes in Europe. Dis Aquat Org 57:201-212

Björklund HV, Olesen NJ, Jørgensen PEV (1994) Biophysical and serological characterization of rhabdovirus 903/87 isolated from European lake trout Salmo trutta lacustris. Dis Aquat Org 19:21-26

Carstens EB (2010) Ratification vote on taxonomic proposals to the International Committee on Taxonomy of Viruses (2009). Arch Virol 155:133-146

Chen HL, Liu H, Liu ZX, He JQ, Gao LY, Shi XJ, Jiang YL (2009) Characterization of the complete genome sequence of pike fry rhabdovirus. Arch Virol 154:1489-1494

Dannevig BH, Olesen NJ, Jentoft S, Kvellestad A, Taksdal T, Hastein T (2001) The first isolation of a rhabdovirus from perch (Perca fluviatilis) in Norway. Bull Eur Assoc Fish Pathol 21:186-194

de Kinkelin P, Galimard B, Bootsma R (1973) Isolation and identification of the causative agent of 'red disease' of pike (Esox lucius L. 1766). Nature 241:265-267

Dietzgen R, Calisher C, Kurath G, Kuzman I and others (2011) Family Rhabdoviridae. In: King AMQ, Adams MJ, Carstens EB, Lefkowitz EJ (eds) Virus taxonomy. Ninth report of the International Committee on Taxonomy of Viruses. Elsevier Academic Press, San Diego, CA, p 654-681, 686-714

> Dixon PF, Longshaw CB (2005) Assessment of commercial test kits for identification of spring viraemia of carp virus. Dis Aquat Org 67:25-29

> Dorson M, Torchy C, Chilmonczyk S, Dekinkelin P, Michel C (1984) A rhabdovirus pathogenic for perch, Perca fluviatilis L. Isolation and preliminary study. J Fish Dis 7: 241-245

Fijan N, Sulimanovic D, Bearzotti M, Muzinic D and others (1983) Some properties of the Epithelioma papulosum cyprini (EPC) cell line from carp Cyprinus carpio. Ann Inst Pasteur Virol 134:207-220

Galinier R, van Beurden S, Amilhat E, Castric J and others (2012) Complete genomic sequence and taxonomic posi- tion of eel virus European X (EVEX), a rhabdovirus of European eel. Virus Res 166:1-12

Hoffmann B, Beer M, Schütze H, Mettenleiter TC (2005) Fish rhabdoviruses: molecular epidemiology and evolution. Curr Top Microbiol Immunol 292:81-117

ICTV (International Committee on Taxonomy of Viruses) (2013a) The ICTV official taxonomy: updates since the 8th Report. Available at http://talk.ictvonline.org/files/ ictv_official_taxonomy_updates_since_the_8th_report/ m/vertebrate-official/4491.aspx (accessed 26 February 2013)

ICTV (International Committee on Taxonomy of Viruses) (2013b) The ICTV taxonomy proposals - vertebrate. Available at http://talk.ictvonline.org/files/proposals/ taxonomy_proposals_vertebrate1/m/vert01/4206.aspx (accessed 26 February 2013)

> Johansson T, Nylund S, Olesen NJ, Björklund H (2001) Molecular characterisation of the nucleocapsid protein gene, glycoprotein gene and gene junctions of rhabdovirus 903/87, a novel fish pathogenic rhabdovirus. Virus Res 80:11-22

> Johansson T, Östman-Myllyoja L, Hellström A, Martelius S, Olesen NJ, Björklund H (2002) A novel fish rhabdovirus from Sweden is closely related to the Finnish rhabdovirus 903/87. Virus Genes 25:127-138

Johnson MC, Simon BE, Kim CH, Leong JA (2000) Production of recombinant snakehead rhabdovirus: the NV protein is not required for viral replication. J Virol 74:2343-2350

Jørgensen PEV, Olesen NJ, Ahne W, Wahli T, Meier W (1993) Isolation of a previously undescribed rhabdovirus from pike Esox lucius. Dis Aquat Org 16:171-179

Koski P, Hill BJ, Way K, Neuvonen E, Rintamäki P (1992) A rhabdovirus isolated from brown trout (Salmo trutta m. lacustris (L)) with lesions in parenchymatous organs. Bull Eur Assoc Fish Pathol 12:177-180

Kurath G, Higman KH, Björklund HV (1997) Distribution and variation of NV genes in fish rhabdoviruses. J Gen Virol 78:113-117

Kuzmin IV, Novella IS, Dietzgen RG, Padhi A, Rupprecht CE (2009) The rhabdoviruses: biodiversity, phylogenetics, and evolution. Infect Genet Evol 9:541-553

Larkin MA, Blackshields G, Brown NP, Chenna R and others (2007) Clustal W and Clustal X version 2.0. Bioinformatics 23:2947-2948

Lorenzen N, Olesen NJ, Vestergård Jörgensen PE (1988) Production and characterization of monoclonal antibodies to four Egtved virus structural proteins. Dis Aquat Org 4:35-42

Midtlyng P, Bleie H, Helgason S, Jansson E and others (2000) Nordic manual for the surveillance and diagnosis of infectious diseases in farmed salmonids. AKA-PRINT A/S, Århus

Mork C, Hershberger P, Kocan R, Batts W, Winton J (2004) Isolation and characterization of a rhabdovirus from starry flounder (Platichthys stellatus) collected from the northern portion of Puget Sound, Washington, USA. J Gen Virol 85:495-505

Nougayrede P, de Kinkelin P, Chilmonczyk S, Vuillaume A (1992) Isolation of a rhabdovirus from the pike-perch [Stizostedion lucioperca (L. 1758)]. Bull Eur Assoc Fish Pathol 12:5-7

Raja-Halli M, Vehmas TK, Rimaila-Pärnänen E, Sainmaa S, Skall HF, Olesen NJ, Tapiovaara H (2006) Viral haemorrhagic septicaemia (VHS) outbreaks in Finnish rainbow trout farms. Dis Aquat Org 72:201-211 
Rowley H, Graham DA, Campbell S, Way K, Stone DM, Curran WL, Bryson DG (2001) Isolation and characterisation of rhabdovirus from wild common bream Abramis brama, roach Rutilus rutilus, farmed brown trout Salmo trutta and rainbow trout Oncorhynchus mykiss in Northern Ireland. Dis Aquat Org 48:7-15

Schütze H, Mundt E, Mettenleiter TC (1999) Complete genomic sequence of viral hemorrhagic septicemia virus, a fish rhabdovirus. Virus Genes 19:59-65

Stone DM, Kerr RC, Hughes M, Radford AD, Darby AC (2013) Characterisation of the genomes of four putative vesiculoviruses: tench rhabdovirus, grass carp rhabdovirus, perch rhabdovirus and eel rhabdovirus European X. Arch Virol, doi 10.1007/s00705-013-1711-x

Talbi C, Cabon J, Baud M, Bourjaily M, de Boisseson C, Castric J, Bigarre L (2011) Genetic diversity of perch rhabdoviruses isolates based on the nucleoprotein and glycoprotein genes. Arch Virol 156:2133-2144

Tamura K, Peterson D, Peterson N, Stecher G, Nei M, Kumar S (2011) MEGA5: molecular evolutionary genetics analy-

Editorial responsibility: Mark Crane,

Geelong, Victoria, Australia sis using maximum likelihood, evolutionary distance, and maximum parsimony methods. Mol Biol Evol 28: 2731-2739

- Tao JJ, Zhou GZ, Gui JF, Zhang QY (2008) Genomic sequence of mandarin fish rhabdovirus with an unusual small non-transcriptional ORF. Virus Res 132:86-96

Teng Y, Liu H, Lv JQ, Fan WH, Zhang QY, Qin QW (2007) Characterization of complete genome sequence of the spring viremia of carp virus isolated from common carp (Cyprinus carpio) in China. Arch Virol 152: 1457-1465

Wagner RR (ed) (1987) The rhabdovirus. Plenum Press, New York, NY

Way K, Bark SJ, Longshaw CB, Denham KL and others (2003) Isolation of a rhabdovirus during outbreaks of disease in cyprinid fish species at fishery sites in England. Dis Aquat Org 57:43-50

- Wolf K, Gravell M, Malsberger RG (1966) Lymphocystis virus: isolation and propagation in centrarchid fish cell lines. Science 151:1004-1005

Submitted: January 28, 2013; Accepted: July 26, 2013 Proofs received from author(s): September 27, 2013 